\title{
Front Matter: Volume 8090
}

, "Front Matter: Volume 8090," Proc. SPIE 8090, Novel Biophotonic

Techniques and Applications, 809001 (7 July 2011); doi: 10.1117/12.903808

SPIE. Event: European Conferences on Biomedical Optics, 2011, Munich, Germany 


\title{
Novel Biophotonic Techniques and Applications
}

\author{
Henricus J. C. M. Sterenborg \\ I. Alex Vitkin \\ Editors
}

\section{2-24 May 2011 \\ Munich, Germany}

Sponsored and Published by

SPIE

The Optical Society of America (United States)

Cooperating Organisations

Deutsche Gesellschaft für Lasermedizin (Germany)

Visions for Better Healthcare-Biophotonics Research Program (Germany)

With Support From

Air Force Office of Scientific Research (United States)

Photonics 4 Life-European Network of Excellence for Biophotonics (Germany)

Student Award Sponsors

Toptica Photonics AG (Germany)

ThorLabs (United Kingdom) 
The papers included in this volume were part of the technical conference cited on the cover and title page. Papers were selected and subject to review by the editors and conference program committee. Some conference presentations may not be available for publication. The papers published in these proceedings reflect the work and thoughts of the authors and are published herein as submitted. The publisher is not responsible for the validity of the information or for any outcomes resulting from reliance thereon.

Please use the following format to cite material from this book:

Author(s), "Title of Paper," in Novel Biophotonic Techniques and Applications, edited by Henricus J. C. M. Sterenborg, I. Alex Vitkin, Proceedings of SPIE-OSA Biomedical Optics Vol. 8090 (SPIE, Bellingham, WA, 2011) Article CID Number.

ISSN 1605-7422

ISBN 9780819486875

Copublished by

SPIE

P.O. Box 10, Bellingham, Washington $98227-0010$ USA

Telephone +1 3606763290 (Pacific Time) · Fax +1 3606471445

SPIE.org

and

Optical Society of America

2010 Massachusetts Ave., N.W., Washington, D.C., 20036 USA

Telephone 1 202/223-8130 (Eastern Time) · Fax 1 202/223-1096

http://www.osa.org

Copyright (@ 2011, Society of Photo-Optical Instrumentation Engineers and Optical Society of America

Copying of material in this book for internal or personal use, or for the internal or personal use of specific clients, beyond the fair use provisions granted by the U.S. Copyright Law is authorized by SPIE subject to payment of copying fees. The Transactional Reporting Service base fee for this volume is $\$ 18.00$ per article (or portion thereof), which should be paid directly to the Copyright Clearance Center (CCC), 222 Rosewood Drive, Danvers, MA 01923. Payment may also be made electronically through CCC Online at copyright.com. Other copying for republication, resale, advertising or promotion, or any form of systematic or multiple reproduction of any material in this book is prohibited except with permission in writing from the publisher. The CCC fee code is $1605-7422 / 11 / \$ 18.00$.

Printed in the United States of America.

Publication of record for individual papers is online in the SPIE Digital Library.

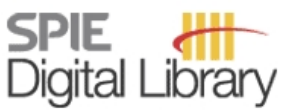

SPIEDigitalLibrary.org

Paper Numbering: Proceedings of SPIE follow an e-First publication model, with papers published first online and then in print and on CD-ROM. Papers are published as they are submitted and meet publication criteria. A unique, consistent, permanent citation identifier (CID) number is assigned to each article at the time of the first publication. Utilization of CIDs allows articles to be fully citable as soon as they are published online, and connects the same identifier to all online, print, and electronic versions of the publication. SPIE uses a six-digit CID article numbering system in which:

- The first four digits correspond to the SPIE volume number.

- The last two digits indicate publication order within the volume using a Base 36 numbering system employing both numerals and letters. These two-number sets start with 00, 01, 02, 03, 04, 05, 06, 07, 08, $09,0 A, O B \ldots 0 Z$, followed by 10-1Z, 20-2Z, etc.

The CID number appears on each page of the manuscript. The complete citation is used on the first page, and an abbreviated version on subsequent pages. Numbers in the index correspond to the last two digits of the six-digit CID number. 


\section{Contents}

vii Conference Committee
ix Introduction

NOVEL IMAGING APPROACHES

809002 An endoscopic structured lighting probe using spectral encoding [8090-01]

N. T. Clancy, D. Stoyanov, G.-Z. Yang, D. S. Elson, Imperial College London (United Kingdom)

809004 Cell death detection and ionic homeostasis monitoring with digital holographic microscopy [8090-03]

N. Pavillon, Ecole Polytechnique Fédérale de Lausanne (Switzerland); J. Kühn, Ecole Polytechnique Fédérale de Lausanne (Switzerland) and CHUV (Switzerland); P. Jourdain, C. Depeursinge, Ecole Polytechnique Fédérale de Lausanne (Switzerland); P. J. Magistretti, P. Marquet, CHUV (Switzerland) and Ecole Polytechnique Fédérale de Lausanne (Switzerland)

809005 Holographic microscopy for the three-dimensional exploration of light scattering from gold nanomarkers in biological media [8090-04]

F. Joud, F. Verpillat, P. Desbiolles, Lab. Kastler Brossel, Univ. Pierre et Marie Curie (France); M. Abboud, Univ. Saint-Joseph (Lebanon); M. Gross, Lab. Kastler Brossel, Univ. Pierre et Marie Curie (France) and Lab. Charles Coulomb, Univ. Montpellier II (France)

809006 Fourier phase contrast multimodal optical microscopy for real time display of phase and fluorescence at the same time [8090-05]

C. S. Yelleswarapu, B. Das, A. Veraksa, D. V. G. L. N. Rao, Univ. of Massachusetts Boston (United States)

809007 Functional imaging of tumor vascular network in small animal models [8090-06] V. Kalchenko, N. Madar-Balakirski, Y. Kuznetsov, Weizmann Institute of Science (Israel); I. Meglinski, Univ. of Otago (New Zealand); A. Harmelin, Weizmann Institute of Science (Israel)

\section{EMERGING TECHNOLOGIES: MODELS AND PLATFORMS I}

8090 OA Lung cancer targeted Raman active phospholipid gold nanoparticles for ultrasensitive and specific molecular imaging and detection [8090-10]

N. C. M. Tam, B. M. T. Scott, B. C. Wilson, G. Zheng, Univ. of Toronto (Canada) and Ontario Cancer Institute, University Health Network (Canada) 
8090 OB Development of Au/Ag substrate with alternating nanosphere array for SERS-based biosensing [8090-11]

C. Y. Fu, National Univ. of Ireland Galway (Ireland) and Singapore Bioimaging Consortium (Singapore); U. S. Dinish, Singapore Bioimaging Consortium (Singapore); K. W. Kho, National Univ. of Ireland Galway (Ireland); D. G. Wenda, Singapore Bioimaging Consortium (Singapore); M. Olivo, National Univ. of Ireland, Galway (Ireland), Singapore Bioimaging Consortium (Singapore), Royal College of Surgeons Ireland (Ireland), and National Univ. of Singapore (Singapore)

8090 OC Investigation of protein aggregation dynamics with a Bloch surface wave sensor [8090-12] V. Paeder, S. Santi, V. Musi, H. P. Herzig, Ecole Polytechnique Fédérale de Lausanne (Switzerland)

\section{EMERGING TECHNOLOGIES: MODELS AND PLATFORMS II}

8090 OD Polymer waveguide platform for highly integrated biophotonics [8090-13]

H. Keshmiri, B. Agnarsson, K. Leósson, Univ. of Iceland (Iceland)

8090 OE Mesh-based Monte Carlo code for fluorescence modeling in complex tissues with irregular boundaries [8090-14]

R. H. Wilson, L.-C. Chen, W. Lloyd, S. Kuo, C. Marcelo, S. E. Feinberg, M-A. Mycek, Univ. of Michigan (United States)

8090 OG Fabrication and characterization of a real-time optical fiber dosimeter probe [8090-16] A. Croteau, S. Caron, Institut National d'Optique (Canada); A. Rink, D. Jaffray, Princess Margaret Hospital, Univ. of Toronto (Canada); O. Mermut, Institut National d'Optique (Canada)

$8090 \mathrm{OH}$ Comparison of Monte Carlo simulations of polarized light propagation in turbid media with exact Maxwell solutions [8090-17]

A. Hohmann, F. Voit, J. Schäfer, A. Kienle, Institut für Lasertechnologien in der Medizin und Meßtechnik (Germany)

\section{PHOTOACOUSTIC TECHNIQUES}

8090 OK Photoacoustic section imaging with an integrating cylindrical detector [8090-20]

S. Gratt, K. Passler, R. Nuster, G. Paltauf, Karl-Franzens-Univ. Graz (Austria)

$8090 \mathrm{OL} \quad$ Enlarged acceptance angle of a finite size detector in photoacoustic imaging using acoustic lenses [8090-21]

W. Xia, D. Piras, M. Heijblom, J. C. G. Van Hespen, Univ. of Twente (Netherlands); S. Van Veldhoven, C. Prins, Oldelft Ultrasound B.V. (Netherlands); W. Steenbergen, Univ. of Twente (Netherlands); T. G. van Leeuwen, Univ. of Twente (Netherlands) and Univ. of Amsterdam (Netherlands); S. Manohar, Univ. of Twente (Netherlands) 
8090 OR Classification of the micro and nanoparticles and biological agents by neural network analysis of the parameters of optical resonance of whispering gallery mode in dielectric microspheres [8090-24]

V. A. Saetchnikov, E. A. Tcherniavskaia, Belarusian State Univ. (Belarus); G. Schweiger,

A. Ostendorf, Ruhr-Univ. Bochum (Germany)

8090 OS Optical nanotechnology enables rapid label-free diagnostics for cancer biomarker screening [8090-25]

D. Wawro, S. Zimmerman, Resonant Sensors Inc. (United States); R. Magnusson, Resonant Sensors Inc. (United States) and The Univ. of Texas at Arlington (United States); P. Koulen, Univ. of Missouri-Kansas City (United States)

8090 OT NIR tracking assists sports medicine in junior basketball training [8090-26]

R. Paeglis, K. Bluss, Biomechanics and Physical Research Institute (Latvia); A. Rudzitis, A. Spunde, Latvian Academy of Sports Education (Latvia); T. Brice, Univ. of Latvia (Latvia); E. Nitiss, Biomechanics and Physical Research Institute (Latvia)

8090 OU Time-resolved diffuse optical spectroscopy up to $1700 \mathrm{~nm}$ using a time-gated InGaAs/InP single-photon avalanche diode [8090-27]

I. Bargigia, A. Tosi, A. Bahgat Shehata, Politecnico di Milano (Italy); A. Della Frera, Micro Photon Devices S.r.I. (Italy); A. Farina, A. Bassi, P. Taroni, A. Dalla Mora, Politecnico di Milano (Italy); F. Zappa, Politecnico di Milano (Italy) and Micro Photon Devices S.r.l. (Italy); A. Pifferi, Politecnico di Milano (Italy) and Istituto di Fotonica e Nanotecnologie (Italy)

$8090 \mathrm{OV}$ Upconversion luminophores as a novel tool for deep tissue imaging [8090-28]

A. P. Popov, A. V. Bykov, Univ. of Oulu (Finland) and Lomonosov Moscow State Univ. (Russian Federation); V. I. Sokolov, Y. V. Lysak, Institute on Laser and Information Technologies (Russian Federation); A. Nadort, Macquarie Univ. (Australia) and Academic Medical Ctr. (Netherlands); A. V. Priezzhev, Lomonosov Moscow State Univ. (Russian Federation); R. Myllylä, Univ. of Oulu (Finland); A. V. Zvyagin, Macquarie Univ. (Australia)

8090 OW A photoplethysmography device for multipurpose blood circulatory system assessment [8090-29]

E. Kviesis-Kipge, J. Zaharans, O. Rubenis, A. Grabovskis, Univ. of Latvia (Latvia)

8090 0X Usability of photoplethysmography method in estimation of conduit artery stiffness [8090-30] A. Grabovskis, Z. Marcinkevics, Z. Lukstina, M. Majauska, J. Aivars, V. Lusa, A. Kalinina, Univ. of Latvia (Latvia)

8090 OY Instrumentation and method for measuring NIR light absorbed in tissue during MR imaging in medical NIRS measurements [8090-31]

T. S. Myllylä, H. S. S. Sorvoja, Univ. of Oulu (Finland); J. Nikkinen, O. Tervonen, V. Kiviniemi, Oulu Univ. Hospital (Finland); R. A. Myllylä, Univ. of Oulu (Finland)

809011 Operating point stabilization of fiber-based line detectors for photoacoustic imaging [8090-34]

K. Felbermayer, H. Grün, T. Berer, P. Burgholzer, RECENDT GmbH (Austria) 
809012 Annular piezoelectric ring array for photoacoustic imaging [8090-35]

K. Passler, R. Nuster, S. Gratt, Karl-Franzens-Univ. Graz (Austria); P. Burgholzer, RECENDT, GmbH (Austria); G. Paltauf, Karl-Franzens-Univ. Graz (Austria)

809013 Time-shifting correction in optoacoustic tomographic imaging for media with non-uniform speed of sound [8090-36]

X. L. Deán-Ben, V. Ntziachristos, D. Razansky, Technical Univ. of Munich and Helmholtz Ctr. Munich (Germany)

809014 Correction for acoustic attenuation effects in optoacoustic tomographic reconstructions [8090-37]

X. L. Deán-Ben, D. Razansky, V. Ntziachristos, Technical Univ. of Munich and Helmholtz Ctr. Munich (Germany)

809015 Monte Carlo simulation of light reflection from cosmetic powders on the skin [8090-39] T. Okamoto, M. Motoda, Kyushu Institute of Technology (Japan); T. Igarashi, K. Nakao, KAO Corp. (Japan)

809016 Improving neuronavigation through workflow and sound feedback and interactive brainshift correction [8090-40]

H. J. Noordmans, P. A. Woerdeman, E. H. J. Voormolen, S. Van der Steen, M. van Stralen, Univ. Medical Ctr. Utrecht (Netherlands)

809017 Measurement of the acoustic scatterers distribution within the imaged sample in an optoacoustic tomographic setup [8090-42]

X. L. Deán-Ben, D. Razansky, V. Ntziachristos, Technical Univ. of Munich and Helmholtz Ctr. Munich (Germany)

809018 Laser speckle contrast vs. depolarization: a solid skin phantom study [8090-44] L. Tchvialeva, G. Dhadwal, D. Diao, Vancouver Coastal Health Research Institute (Canada) and Univ. of British Columbia (Canada); H. Lui, Vancouver Coastal Health Research Institute (Canada), Univ. of British Columbia (Canada), and BC Cancer Research Ctr. (Canada); D. I. McLean, Vancouver Coastal Health Research Institute (Canada) and Univ. of British Columbia (Canada); T. K. Lee, Vancouver Coastal Health Research Institute (Canada), Univ. of British Columbia (Canada), BC Cancer Research Ctr. (Canada), and Simon Fraser Univ. (Canada)

809019 Three dimensional tracking of gold nanoparticles using digital holographic microscopy [8090-49]

F. Verpillat, F. Joud, P. Desbiolles, M. Gross, École Normale Supérieure (France)

Author Index 


\title{
Conference Committee
}

\author{
General Chairs
}

Christoph K. Hizenberger, Medizinische Universität Wien (Austria)

Brian W. Pogue, Dartmouth College (United States)

Programme Chairs

Peter E. Andersen, Technical University of Denmark (Denmark)

Irene Georgakoudi, Tufts University (United States)

Conference Chairs

Henricus J. C. M. Sterenborg, Erasmus MC (Netherlands)

I. Alex Vitkin, University of Toronto (Canada)

Program Committee

Arjen Amelink, Erasmus MC (Netherlands)

Vanderlei Salvador Bagnato, Universidade de São Paulo (Brazil)

Paul C. Beard, University College London (United Kingdom)

Daniel Cote, Centre de recherche de l'Université Laval Robert-Giffard (Canada)

Stanislav Y. Emelianov, The University of Texas at Austin (United States)

Dirk J. Faber, Universiteit van Amsterdam (Netherlands)

Venkataramanan Krishnaswamy, Dartmouth College (United States)

Steen J. Madsen, University of Nevada, Las Vegas (United States)

Igor Meglinski, University of Otago (New Zealand)

Seemantini K. Nadkarni, Harvard Medical School (United States)

Günther Paltauf, Karl-Franzens-Universitaet Graz (Austria)

Gijs van Soest, Erasmus MC (Netherlands)

Chris Xu, Cornell University (United States)

Session Chairs

1 Novel Imaging Approaches

I. Alex Vitkin, University of Toronto (Canada)

2 Emerging Technologies: Models and Platforms I

Seemantini K. Nadkarni, Harvard Medical School (United States)

3 Emerging Technologies: Models and Platforms II

Arjen Amelink, Erasmus MC (Netherlands) 
Photoacoustic Techniques

Henricus J. C. M. Sterenborg, Erasmus MC (Netherlands)

Advanced Biophotonics-Sensing and Imaging: Joint Session with Conference 8091

Irene Georgakoudi, Tufts University (United States)

Kishan Dholakia, University of St. Andrews (United Kingdom)

Poster Session

I. Alex Vitkin, University of Toronto (Canada)

Henricus J. C. M. Sterenborg, Erasmus MC (Netherlands) 


\section{Introduction}

The European Conference on Biomedical Optics (ECBO), part of World of Photonics Congress / 20th International Congress on Photonics in Europe, took place in Munich, Germany on 22-26 May 2011. Its approximately 500 attendees were treated to five days of talks, posters, technical exhibits, and special events, with ample opportunities for discussing biophotonics science, making personal and scientific connections, and finding out the latest trends in our rapidly evolving interdisciplinary field. The ECBO program was organized into seven thematic subconferences, and the chairs of each solicited manuscripts from their respective oral and poster presenters. These were compiled into the 2011 ECBO proceedings volumes, with the one you are currently holding in your hands containing selected manuscripts from the Novel Biophotonic Techniques and Applications (NBTA) sub-conference.

The NBTA presentations were thematically diverse, as indicated by the session titles: Novel Imaging Approaches, Emerging Technologies: Models and Platforms, Photoacoustic Techniques, etc. As you read this volume, you will encounter interesting biophotonics studies using holographic, endoscopic, polarimetric, coherent, spectroscopic, speckle, photoacoustic, and other novel methods for advanced tissue assessment. Work on nanoparticle constructs, intravital microscopies, and light-tissue interaction models were also well represented at NBTA. Such breadth and variety nicely illustrates the diversity of research in this exciting field. We hope that as you read this and the other six proceedings volumes of the EBCO 2011, you will be inspired to (continue to) actively contribute to biophotonics research!

Henricus J. C. M. Sterenborg I. Alex Vitkin 
Downloaded From: https://www.spiedigitallibrary.org/conference-proceedings-of-spie on 26 Apr 2023

Terms of Use: https://www.spiedigitallibrary.org/terms-of-use 